\title{
Oral manifestations in chronic kidney failure patients
}

Renata Cristina Canuto Reis ${ }^{\mathrm{a}}$, João Armando Brancher ${ }^{\mathrm{b}}$, Tatiana Miranda Deliberador ${ }^{\mathrm{b}}$, Ana Tereza Bittencourt Guimarães ${ }^{c}$, Allan Fernando Giovaninib, João Cézar Zielakb

\begin{abstract}
Objective: Chronic kidney failure (CKF) is a progressive deterioration of the kidneys. The goal of this study was to analyze the oral manifestation of CKF in a sample of hemodialysis and transplanted patients.

Methods: Eighty-three records of patients treated in the Pro-Renal Foundation in Curitiba, Brazil were used. The records were separated in four groups: Transplanted Men (TM = 14), Transplanted Women (TW = 18), Men in Hemodialysis (MHD = 28) and Women in Hemodialysis (WHD = 23). Information about oral and systemic health condition were collected. Data from each group were submitted to correspondence analysis and quantitative variables were compared by Kruskal-Wallis and Dunn's test. Significance level was 0.05 .

Results: Gingival inflammation, loss of periodontal support tissue, dental calculus and increase in periodontal probing depth were common findings in all patients, but significant association was found in following groups: TM presented dental calculus; TW presented a high prevalence of cardiovascular problems and saburral tongue; MHD presented poor oral hygiene, gingivitis associated with smoking; WHD presented a high prevalence of temporomandibular dysfunction.

Conclusions: The most prevalent findings were increase in the periodontal probing depth and gingival recession. Unexpectedly, WHD group presented a high prevalence of temporomandibular dysfunction.
\end{abstract}

Key words: Hemodialysis; Chronic kidney failure; Oral health

\section{Manifestações bucais em pacientes portadores de doença hepática crônica}

\section{RESUMO}

Objetivo: Insuficiência Renal Crônica (IRC) é caracterizada pela perda progressiva dos rins. O objetivo deste estudo foi analisar as manifestações bucais de uma amostra de pacientes renais transplantados ou que faz hemodiálise.

Metodologia: Oitenta e três prontuários de pacientes em atendimento na Fundação Pró-Renal em Curitiba, Brasil foram analisados e quarto grupos foram formados: Homens Transplantados $(H T=14)$, Mulheres Transplantadas ( $M T=18)$, Homens em Hemodiálise $(H H=28)$ e Mulheres em Hemodiálise $(M H=23)$. Informações sobre a saúde bucal e sáude geral foram coletadas. Dados de cada grupo foram submetidos à análise pelo teste Kruskal-Wallis, seguido pelo teste de Dunn com nível de significância de 0,05.

Resultados: Inflamação gingival, perda de tecido periodontal de suporte, cálculo dentário e aumento de profundidade de sondagem foram encontrados em todos os pacientes, mas associações significantes foram encontradas nos seguintes grupos: HT apresentaram alta prevalência de cálculo dentário; problemas cardiovasculares e língua saburosa foi observada em MT; HH são fumantes, apresentam probre higiene bucal e gengivite; em mulheres em hemodiálise foi relatada uma alta prevalência de disfunção temporomandibular. Conclusão: Em geral, os achados mais comuns são aumento de profundidade de sondagem e recessão gingival. Mulheres que realizam sessões de hemodiálise apresentam disfunção tempormandibular.

Palavras-chave: Hemodiálise; Insuficiência renal crônica; Saúde bucal a Post Graduation Student in Dentistry, Positivo University, Curitiba, Paraná

${ }^{b}$ Adjunct Professor, Positivo University, Curitiba, Paraná

${ }^{c}$ Adjunct Professor, Universidade do Oeste do Paraná, Cascavel, Paraná 


\section{INTRODUCTION}

Chronic kidney failure (CKF) is a progressive and irreversible decline of the kidneys function that causes metabolic disarrangements, bone disease, chronic inflammation, accelerated atherosclerosis and cardiovascular disease. The loss of renal function promotes the accumulation of nitrogenous wastes in the blood which contributes to the aggravation of disorders in CKF patients [1]. Dialysis, hemodialysis or kidney transplantation are alternatives for the removal of metabolic waste products in CKF patients [2]. According to the Brazilian Society of Nephrology the prevalence of adult Brazilian individuals with kidney disease have been rising annually, and in 2011 about 91,000 patients underwent dialysis [3].

CKF patients have serious systemic and oral complications. Among the most important systemic complications are cardiovascular diseases, and electrolyte imbalance [4], as well as suppression of immune response and humoral [5], cytomegalovirus infection [6] and exacerbation of inflammatory response [7]. The most frequent oral alterations are mouth dryness [8], decreased bone trabeculation [8], malocclusion and enamel hypoplasia [9], periodontal disease [10] and other less common complications [9].

The goal of the present study was to analyze the oral manifestation of CKF in a well-characterized sample of hemodialysis and transplanted patients treated in the city of Curitiba, Brazil.

\section{METHODS}

This study was performed with the approval of Bioethics Committee of the Positivo University (number 93/08). For the present study we used 83 records of unrelated patients treated in the Pro-Renal Foundation in Curitiba, Brazil. The records were separated in four groups: Men Transplanted (MT; n=14), Women Transplanted (WT; n=18), Men in Hemodialysis (MHD; $\mathrm{n}=28$ ) and Women in Hemodialysis (WHD; $n=23$ ). Information about systemic health and oral conditions was collected. Data from each group were submitted to correspondence analysis (CA) in order to determine which explanatory variables correspond to the groups. Quantitative variables were compared by non parametric Kruskal-Wallis test followed by multiple comparisons using the Dunn test. The significance level was 0.05 .

\section{RESULTS}

The results obtained with the CA for each group of individuals may be observed in Figure 1. The following associations were established among the groups: TM presented dental calculus; TW presented a high prevalence of cardiovascular disease, hepatitis in association with saburral tongue; MHD presented deficiency in oral hygiene, gingivitis and dental attrition associated with smoking habit; WHD presented a high prevalence of temporomandibular dysfunction and decreased visual acuity (Table 1).

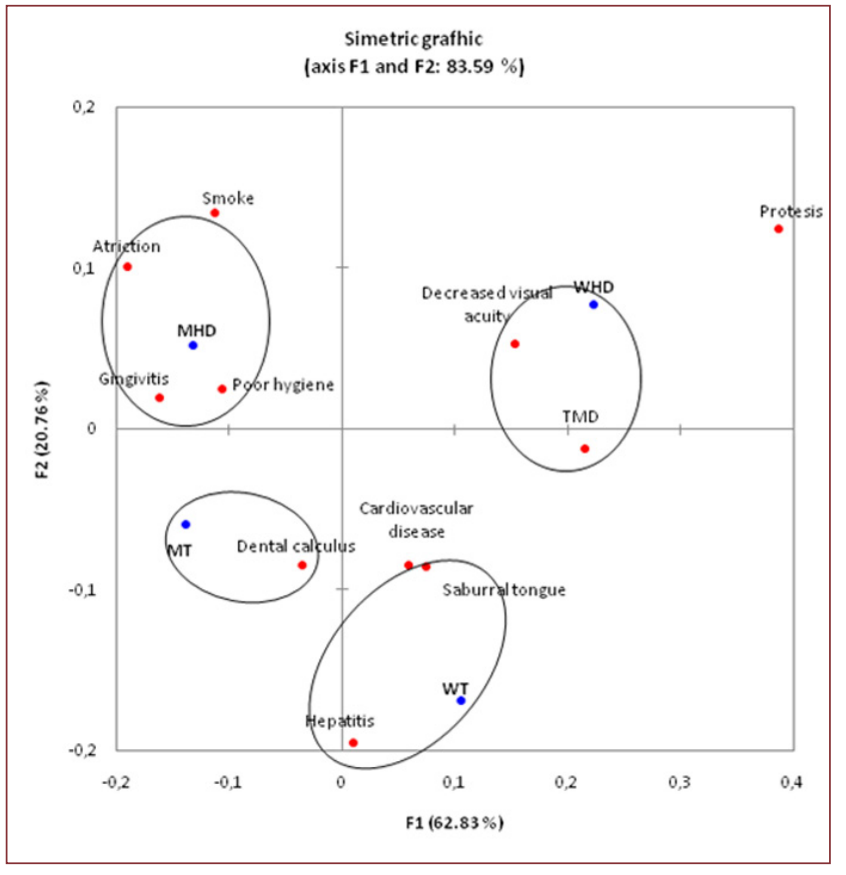

Figure 1. Variables analyzed by CA and ordination axes produced by them. The circles indicate the associations observed in the different groups and the contribution of each variable analyzed. The axis of Factor-1 (F1) is influenced by systemic pathologies developed by patients (positive side) and oral diseases presented by them (negative side). Factor-2 (F2) presents the main contribution of groups of patients, the positive portion of this factor is related to non-transplanted patients and the negative portion, to the transplants. F1 and F2 together explain $83.59 \%$ of data variability.

Table 1. Associations observed between the explanatory variables and the different groups of patients.

\begin{tabular}{ll}
\hline \multicolumn{1}{c}{ Groups } & \multicolumn{1}{c}{ Explanatory Variables } \\
$\begin{array}{l}\text { Men in hemodialysis } \\
\text { (MHD) }\end{array}$ & $\begin{array}{l}\text { Gengivitis, deficiency in oral } \\
\text { hygiene, atriction, and smoke }\end{array}$ \\
$\begin{array}{l}\text { Women in hemodialysis } \\
\text { (WHD) }\end{array}$ & $\begin{array}{l}\text { Decreased visual acuity, } \\
\text { temporomandibular dysfunction }\end{array}$ \\
$\begin{array}{l}\text { Men transplanted } \\
\text { (MT) }\end{array}$ & Dental calculus \\
$\begin{array}{l}\text { Women transplanted } \\
\text { (WT) }\end{array}$ & Cardiovascular disease, saburral \\
\hline
\end{tabular}

Generally, gingival recession and inflammation, loss of periodontal support tissue, dental calculus and increase in the periodontal probing depth were common findings in all records, but significant differences were seen among the groups regarding the number of present teeth $(p<0.0001)$, periodontal index $(p<0.0001)$, probing depth $(p<0.0001)$ and decayed, missing and filled teeth (DMFT) $(\mathrm{p}<0.0001)$ (Table 2). 
Table 2. Descriptive statistics, mean and standard deviation, of the quantitative variables. Comparison between groups by Kruskal-Wallis test and Dunn's test.

\begin{tabular}{lcccc}
\hline & $\begin{array}{c}\text { MT } \\
(n=14)\end{array}$ & $\begin{array}{c}\text { WT } \\
(n=18)\end{array}$ & $\begin{array}{c}\text { MHD } \\
(n=28)\end{array}$ & $\begin{array}{c}\text { WHD } \\
(\mathbf{n}=\mathbf{2 3})\end{array}$ \\
Mean age & $40.1 \pm 8.9(\mathrm{ab})$ & $39.6 \pm 10.5(\mathrm{a})$ & $48.4 \pm 12.2(\mathrm{~b})$ & $46.9 \pm 14.6(\mathrm{ab})$ \\
DMFT & $5.9 \pm 4.3(\mathrm{~b})$ & $5.4 \pm 3.1(\mathrm{~b})$ & $5.8 \pm 4.6(\mathrm{~b})$ & $3.7 \pm 3.7(\mathrm{a})$ \\
Teeth present & $23.2 \pm 9.3(\mathrm{~b})$ & $21.9 \pm 7.1(\mathrm{ab})$ & $23.6 \pm 7.7(\mathrm{~b})$ & $16.1 \pm 10.1(\mathrm{a})$ \\
Periodontal index & $2.9 \pm 0.5(\mathrm{~b})$ & $2.5 \pm 0.7(\mathrm{a})$ & $2.9 \pm 0.3(\mathrm{~b})$ & $2.6 \pm 0.7(\mathrm{ab})$ \\
Gingival inflammation index & $2.6 \pm 0.6(\mathrm{a})$ & $2.5 \pm 0.5(\mathrm{a})$ & $3.1 \pm 4.0(\mathrm{a})$ & $2.5 \pm 0.5(\mathrm{a})$ \\
Periodontal probing depth & $5.4 \pm 1.5(\mathrm{~b})$ & $4.9 \pm 1.6(\mathrm{~b})$ & $5.6 \pm 2.3(\mathrm{~b})$ & $4.2 \pm 2.1(\mathrm{a})$ \\
\hline
\end{tabular}

* Different letters show statistical differences.

\section{DISCUSSION}

CKF transplanted or in dialysis treatment patients demonstrate important metabolic alterations such as changes in biochemical parameters of blood, elevated triglycerides [11] and hyperuricemia [12]. Systemic arterial hypertension [13], electrolyte imbalance [4] and recurrent inflammatory conditions with a large release of inflammatory mediators [7] are other conditions also associated with CKF.

Poor oral care is frequently seen in CKF patients [8], therefore, several studies show that periodontal tissues are often affected by gingivitis and periodontal disease, with loss of attachment of the support tissues [8]. Periodontal tissues can be evaluated by probing depth, index of gingival inflammation and visible plaque index [14]. In this study, gingival recession and inflammation, periodontal disease, loss of support tissue, dental calculus, increase in the periodontal probing depth, increase in visible plaque and gingival inflammation indexes were observed in all records. The visible plaque index was higher than the reported literature for patients with renal disease [15]. MHD and TM showed higher indices of gingival inflammation, probing depth and visible plaque when compared to women. In correspondence statistical analysis, MHD had gingivitis, poor oral hygiene and dental attrition, besides commonly use of tobacco. It is well known that smoking is a risk factor which aggravates periodontitis. Thorman et al. [16] associated the increased rate of visible plaque to significantly increase in oral fungal infections, erythematosus oral stomatitis, candidiasis or angular cheilitis in $37 \%$ of the patients with peritoneal dialysis. In this study, there was no such association.

Craig [17] considers periodontitis a complication of kidney disease. The presence of periodontal disease in CKF patients is complicated by the fact that periodontal pockets can be habitats of bacteria, representing a dangerous source of inflammation and contributing to increased systemic frameworks, morbidity and mortality of these patients [18]. In the present study, all records showed the patients with periodontal disease, at higher or lower stage of evolution, denoting an additional risk for these patients.

Several hypotheses have been proposed to explain the increase in the periodontitis activity in individuals with kidney disease. Psychological factors associated with depressive symptoms, decreased activity of the immune system and use of drugs, especially anticoagulants that enhance gingival bleeding and increased salivary urea with consequent change in the oral microbiota [19] seem to explain the evolution of periodontal disease in these individuals. Importantly, the patients of the present study are treated at an institution that provides continually programs for oral health and dental care, but the motivation and participation of the individual must be constant to minimize the risk of infections.

Due to the increased presence of plaque and also to a probable high-carbohydrate diet, it is expected that the DMFT index also increases in these patients, but several studies have shown a low prevalence of caries in CKF patients. This condition can be attributed to the increased concentration of urea and high salivary buffering capacity of these patients [20]. Contrary to the literature, the group of patients in this study had a higher prevalence of caries $(\mathrm{TM}=5.9 \pm 4.3, \mathrm{TW}=5.4 \pm 3.1$, MHD $5.8 \pm 4.6$ and WHD $3.7 \pm 3.7)$. These values are considered high, even when compared to other groups of renal patients [21]. It is possible to assume that this higher prevalence of caries can also be attributed to a previous CKF oral history. However, the prevalence of dental caries was lower in WHD and differed significantly from the other groups. Generally, women presented lower DMFT, plaque index, gingival inflammation and lower probing depth, reflected by a better oral hygiene condition than men. The WHD group presented the most favorable oral conditions.

Osteoarticular disorders are common findings in patients with renal disease due to secondary hyperparathyroidism [22]. Thus, lesions may affect long bones. However, the involvement of the jaw is uncommon and appears to be confined to the long-term dialysis patients [23]. In this study, the records revealed a trend for increased temporomandibular complaints in patients in hemodialysis. $33.3 \%$ of these patients, 10 men and 7 women in hemodialysis, had some type of temporomandibular disorder. In the study of Bots et al. [24] 16.5\% of patients with CKF undergoing dialysis therapy demonstrated temporomandibular complaints. Yamamoto et al. [25] observe that CKF patients develop amyloidosis, known as Dialysis Related Amyloidosis (DRA). 
DRA causes severe osteoarticular lesion in patients under hemodialysis, associated with the duration of the therapy. These authors show that patients with 30 years of dialysis acquire serious complications from osteoarticular disorders. In the WHD group of the present study, the correspondence analysis also showed a strong association between temporomandibular dysfunction and decreased visual acuity.

The prevalence of gingival inflammation and dental calculus was significantly higher in all patients. The most prevalent findings were increase in the periodontal probing depth, visible plaque index and gingival inflammation. Overall, both men and women showed poor oral hygiene, although in men this was more distinctive. Unexpectedly, the WHD group presented a high prevalence of temporomandibular dysfunction.

\section{REFERENCES}

1. Stenvinkel P, Carrero JJ, Axelsson J, Lindholm B, Heimburger O, Massy Z. Emerging biomarkers for evaluating cardiovascular risk in the chronic kidney disease patient: How do new pieces fit into the uremic puzzle? Clin J Am Soc Nephrol. 2008;3:505-21.

2. Chan JC, Williams DM, Roth KS. Kidney failure in infants and children Pediatr Rev. 2002;23:47-60.

3. Censo da SBN Jan/2011. Available at: http:// www.sbn.org.br. Accessed may 26, 2012

4. Proctor R, Kumar N, Stein A, Moles D, Porter S. Oral and dental aspects of chronic renal failure. J Dent Res. 2005;84:199-208.

5. Bokor-Bratic M. Clinical significance of analysis of immunoglobulin A levels in saliva. Med Pregl. 2000;53:164-68.

6. López-Pintor RM, Hernández G, de Arriba L, Morales JM, Jiménez C, de Andrés A. Oral ulcers during the course of cytomegalovirus infection in renal transplant recipients. Transplant Proc. 2009;41(6):2419-21.

7. Carrero JJ, Stenvinkel P. Persistent Inflammation as a Catalyst for Other Risk Factors in Chronic Kidney Disease: A Hypothesis Proposal. Clin J Am Soc Nephrol. 2009;4:49-55.

8. Souza CM, Braosi AP, Luczyszyn SM, Casagrande RW, Pecoits-Filho R Riella MC, Ignacio SA, Trevilatto PC. Oral health in Brazilian patients with chronic renal disease. Rev Med Chil. 2008;136:741-6

9. Hata T, Irei I, Tanaka K, Nagatsuka H, Hosoda M: Macrognathia secondary to dialysis-related renal osteodystrophy treated successfully by parathyroidectomy. Int J Oral Maxillofac Surg. 2006;35:378-82.

10. Jacek Borawski, Magdalena Wilczyńska-Borowska, Wanda Stokowska Michał Myśliwiec. The periodontal status of pre-dialysis chronic kidney disease and maintenance dialysis patients. Nephrology, dialysis, transplantation: official publication of the European Dialysis and Transplant Association. European Renal Association. 2007:22(2):457-64.
11. Vaziri ND. Dyslipidemia of chronic renal failure: the nature, mechanisms, and potential consequences. Am J Physiol Renal Physiol. 2006;290: 262-72.

12. Watanabe S, Noboru M, Yasunari M, Ideura T. A Cross-Sectional Study on the Effects of Long Term Very Low Protein Diets in Patients with Chronic Kidney Disease - Serum and Urine DEXA and Amino Acid Profiles. Anti-aging Med. 2010;7(2):7-13.

13. Levin A, Djurdjev O, Barrett B, Burgess E, Carlisle E, Ethier J, Jindal K, Mendelssohn D, Tobe S, Singer J, Thompson C. Cardiovascular disease in patients with chronic kidney disease: Getting to the heart of the matter. Am J Kidney Dis. 2001;38(6):1398-407.

14. Bayraktar G, Kurtulus I, Kazancioglu R, Bayramgurler I, Cintan S, Bural C Bozfakioglu S, Issever H, Yildiz A. Oral health and inflammation in patients with end-stage renal failure. Perit Dial Int. 2009;29(4):472-9.

15. Marakoglu I, Gursoy UK, Demirer S, Sezer H. Periodontal Status of Chronic Renal Failure Patients Receiving Hemodialysis. Yonsei Med J. 2003;44(4):648-652.

16. Thorman R, Neovius M, Hylander B. Scand J Prevalence and early detection of oral fungal infection: a cross-sectional controlled study in a group of Swedish end-stage renal disease patients. Urol Nephrol. 2009;43(4):325-30.

17. Craig RG, Spittle MA, Levin NW. Importance of periodontal disease in the kidney patient. Blood Purif. 2002;20(1):113-9.

18. Kshirsagar AV, Craig RG, Beck JD, Moss K, Offenbacher S, Kotanko P, Yoshino M, Levin NW, Yip JK, Almas K, Lupovici E, Falk RJ: Severe periodontitis is associated with low serum albumin among patients on maintenance hemodialysis therapy. Clin J Am Soc Nephrol. 2007;2: 239-44.

19. Borawski J, Wilczynska-Borawska M, Stokowska W, Mysliwiec M: The periodontal status of pre-dialysis chronic kidney disease and maintenance dialysis patients. Nephrol Dial Transplant. 2007;22:457-64.

20. Kho HS, Lee SW, Chung SC, Kim YK. Oral manifestations and salivary flow rate, $\mathrm{pH}$, and buffer capacity in patients with endstage renal disease undergoing hemodialysis. Oral Surg Oral Med Oral Pathol Oral Radiol Endod. 1999;88:316-9.

21. Martins C, Siqueira WL, Primo LSSG. Oral and salivary flow characteristics of a group of Brazilian children and adolescents with chronic renal failure. Pediatr Nephrol. 2008;23:619-24.

22. Hruska K. New concepts in renal osteodystrophy. Nephrol Dial Transplant. 1998;13:2755-60.

23. Kalyvas D, Tosios KI, Leventis MD, Tsiklakis K, Angelopoulos AP. Localized jaw enlargement in renal osteodystrophy: report of a case and review of the literature. Oral Surg Oral Med Oral Pathol Oral Radiol Endod. 2004;97:68-74.

24. Bots CP, Poorterman JH, Brand HS, Kalsbeek H, van Amerongen BM Veerman EC, Nieuw Amerongen AV. The oral health status of dentate patients with chronic renal failure undergoing dialysis therapy. Oral Dis. 2006;12(2):176-80.

25. Yamamoto S, Kazama JJ, Narita I, Naiki H, Gejyo F. Recent progress in understanding dialysis-related amyloidosis. Bone. 2009;45(1):39-42. 